\title{
Planothidium scrobiculatum sp. nov. (Bacillariophyta), a new monoraphid diatom from freshwater Pleistocene deposits of South America
}

\author{
Gisele C. Marquardt ${ }^{1 *}$, Denise C. Bicudo ${ }^{2}$, Carlos E. de M. Bicudo ${ }^{2}$, Marie- \\ Pierre LeDRU $^{3}$, Luc Ector ${ }^{4} \&$ Carlos E. WeTZEL ${ }^{4}$
}

\author{
${ }^{1}$ Universidade Guarulhos, Centro de Pós-Graduação, Pesquisa e Extensão CEPPE. Praça Tereza Cristina 88, \\ 07023070 Guarulhos, SP, Brazil; *Corresponding author email: giselecmarquardt@gmail.com

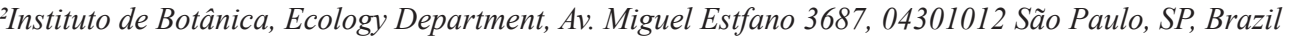 \\ ${ }^{3} I S E M$, Universit Montpellier, CNRS, IRD, EPHE, F34095 Montpellier, France \\ 4Luxembourg Institute of Science and Technology (LIST), Environmental Research and Innovation Department \\ (ERIN), 41 rue du Brill, L4422 Belvaux, Luxembourg
}

\begin{abstract}
A new monoraphid diatom species appeared successively in paleolimnological records from a Quaternary sediment core (1.5 $\pm 0.1 \mathrm{Ma}$ ) retrieved from Colônia basin (Brazilian Coastal Plain, Atlantic Forest, São Paulo Metropolitan Region), and is formally described as Planothidium scrobiculatum sp. nov. We studied the new species through light and scanning electron microscopy and discussed its similarity to other members of the genus. The new species has a unique combination of morphological features that allow its separation from all other species in the genus: (1) lanceolate valve outline with cuneate apices, (2) multiseriate striae composed of two to four rows of irregular sized areolae on the rapheless sternum valve (SV), not interrupted at the valve mantle junction, and (3) arrangement of areolae on the valve mantle, grouped in 3 or 4 rows, each composed of 2 to 3 areolae on the SV. Nevertheless, the new species main diagnostic feature is the occurrence of numerous, unusual, small shallow depressions externally located on the SV along the axial area, cavum, and virgae. As a result, P. scrobiculatum is different from similar species under LM and SEM by some evident characters or a combination of characters. This study contributes to the knowledge of the so far understudied biodiversity of microorganisms of tropical regions. In addition, the above-mentioned diversity patterns and the wealth of new diatom taxa inside and around the Colônia basin (many yet to be described) suggest that further samplings from other localities may provide an insight into its habitat preferences and range, since this area is an exceptional biological entity, worthy of further study.
\end{abstract}

Key words: Colônia basin, fossil diatoms, paleolimnology, Planothidium, Pleistocene, South America, taxonomy

\section{INTRODUCTION}

Planothidium was published by Round \& BuKHTIYARova (1996) to accommodate some diatom specimens related to Achnanthes lanceolata (Brébisson ex Kützing) Grunow (CLEVE \& GRunow 1880), which was formerly considered the type of the genus. The transfer of A. lanceolatum to Planothidium was considered. However, it proved invalid based on the lack of indication of the basionym, which was later on corrected by Lange-Bertalot (LANGEBertalot 1999; VAn de VijVer \& BosaK 2019). VAN de VIJVER et al. (2013) have designated a formal lectotype for this species.

Planothidium currently comprises 62 named species and varieties accepted (KocioLEK et al. 2020). According to Wetzel et al. (2019), representatives of the genus Planothidium are predominantly epilithic or epipsammic. Stancheva (2019) reported that they can also live epiphytic on aquatic plants and algae, seeming to be more diverse in alkaline environments (WETZEL et al. 2019). Most species are from freshwater environments, although some of them may be found in brackish and marine environments (e.g. RIAUX-GobIN et al. 2012, 2018). Planothidium is characterized by a convex rapheless sternum valve (SV) and a slightly concave raphe valve (RV) (STANCHEVA 2019), both valves having multiseriate striae (ROUND \& BUKHTIYAROVA 1996). In the SV, striae may be continuous ('delicatulum' type) or interrupted on one side showing a clear space in the central area. Such interruption may be not associated with any internal depression ('minutissimum' type), or may be accompanied by a 'hoof-mark' ('frequentissimum' type, when the depression is an internal capped structure, the cavum, or 'lanceolatum' type where the depression 
is not capped, the sinus) (RovIRA et al. 2011; VAN DE VIJVER et al. 2013). It was recently suggested that the cavum might act as an optical system that will diffuse or focus light, depending on the refractive index of the matter inside the cavity (BUKHTIYAROVA \& LYAKH 2014).

Recent molecular investigations on Planothidium identified two clear parallel clades, one of the specimens with either a sinus or a cavum and the other lacking both features. Striae ultrastructure and the merged and/ or offset areolae on the valve mantle are also considered of particular taxonomic significance (JAHN et al. 2017). Some authors divided Planothidium specimens without terminal raphe fissures curved to the secondary side (SPAULDING et al. 2008; JAHN et al. 2017). Furthermore, type materials reinvestigation and the use of scanning electron microscopy (SEM) associated with a more precise definition of the new freshwater species from around the world considerably improved the genus taxonomy (STANCHEVA 2019).

Indeed, several populations of one unknown Planothidium species were found during an ongoing paleolimnological collection of a sedimentary core of Pleistocene deposits in Colônia basin (located in the Brazilian Coastal Plain, Atlantic Forest, São Paulo Metropolitan Region). A remarkable Planothidium diversity was documented for the tropical region of South America (e.g. Metzeltin \& LANGE-Bertalot 1998, 2007; RumRICH et al. 2000; METZELTIN et al. 2005). Still, a wide geographical distribution was comprehensively demonstrated for the genus, ranging from North America (e.g. Potapova 2012; Stancheva 2019; Wetzel et al. 2019), Africa (e.g. Gasse 1986; CoCQuYT et al. 1993; CoCQuYt 1998; CoMpÈre \& RiAuX-Gobin 2009; CoMPÈre \& VAN DE VIJVER 2009; N'GUESSAN et al. 2014), Asia (e.g. KuliKovsKiY et al. 2015; WetZeL et al. 2019), Oceania (e.g. Novis et al. 2012), Europe (e.g. Álvarez-Blanco \& Blanco 2013; Blanco et al. 2013; BąK \& LANGE-Bertalot 2014) to the Antarctic region (e.g. VAN DE VIJVER et al. 2013, 2018).

Several studies that includes diatoms have been developed for the Pleistocene period, whether in a paleoenvironmental (e.g. KorSAKOVA et al. 2016; PAnagiotopoulos et al. 2020; Spaulding et al. 2020) or in a taxonomic context (e.g. KACZMARSKA 1981; McLaughlin \& Stone 1986; TANAKA \& Kobayasi 1996). Also, a large number of new fossil species have been recorded for China (GoNG et al. 2013), Japan (TANAKA \& Nagumo 2000; Julius et al. 2006; NAYA 2012), Nepal (Hayashi \& TANimura 2015), Kenya (Brindle et al. 2018), as well as in studies carried out on Baikal Lake (Khursevich et al. 2003) and Black sea (OlshtYNSKA \& TyMchenko 2018). However, only a few studies include monoraphid diatoms, most of which are represented by Achnanthes Bory (some of them currently transferred to Achnanthidium Kützing, Psammothidium Buhtkiyarova et Round and Platessa Lange-Bertalot) and Cocconeis Ehrenberg, rarely accompanied by illustration (e.g. AUER 1959; Wornardt 1964; O’Brien 1968; GASSE 1980;
VANLANDINGHAM 1990; YASUI \& KobaYASHI 2001). Also, a few studies were found to include specifically Planothidium representatives. GAsse (1980) illustrated Planothidium species during a diatom analysis of a continuous and dated Plio-Pleistocene lacustrine sequence from Africa.

Finally, YASUI \& KOBAYASHI (2001) recorded Planothidium representatives in the fossil diatom flora composition of Shiotsugata Lagoon in the Echigo Plain, Japan. In addition to other monoraphid diatom genera, the authors illustrated Achnanthes delicatula (Kützing) Grunow (三Planothidium delicatulum (Kützing) Round et Bukhtiyarova), A. delicatula spp. hauckiana (三P. hauckianum (Grunow) Bukhtiyarova) and A. lanceolata ( $\equiv P$. lanceolatum (Brébisson ex Kützing) Lange-Bertalot).

In Brazil, Wetzel et al. (2013), who described Planothidium incuriatum C.E.Wetzel, Van de Vijver et Ector, found that the species is widely distributed worldwide when carrying out taxonomic studies on Planothidium using samples from southern Brazil (rivers of the Rio Pardo hydrographic basin). Furthermore, Wetzel \& ECTOR (2014a) described the new species $P$. bagualensis C.E.Wetzel et Ector, and highlighted the need of a precise definition on the identity of the most common taxa to improve the accuracy of diagnostic tools that rely on diatom taxonomy and ecology. Finally, WETZEL \& ECTOR (2014b) proposed the new combination Planothidium lagerheimii (Cleve) C.E.Wetzel et Ector (三 Cocconeis lagerheimii Cleve), a common species often reported in freshwater and aerial environments identified in previous studies either as Cocconeis rudis Frenguelli or Planothidium salvadorianum (Hustedt) Lange-Bertalot (三Achnanthes salvadoriana Hustedt). Regarding material from Southeastern Brazil, WeTZEL et al. (2019) described P. brasiliense C.E. Wetzel et S.Blanco when reviewing the types of material from historical collections. Some other authors focused on ecological and floristic surveys (e.g. FerRari \& LUDWIG 2007; FARIA et al. 2010; BARTOZEK et al. 2018), whereas RUWER \& RoDRIGUES (2018) represents the only paleolimnological study using diatoms, in which two Planothidium species (P. bagualensis and P. aff. rostratum (Østrup) LangeBertalot) from the upper Paraná river floodplain over the last $\sim 1000$ years are mentioned and illustrated using both light and scanning electron microscopy.

This study describes a new monoraphid diatom species Planothidium scrobiculatum sp. nov. from the Colônia basin. Detailed examination of LM and SEM microscopy examination of the valve ultrastructure is presented. Morphological comparison is conducted with the most similar taxa based on literature information.

\section{Material ANd Methods}

We sampled the material used in this study from a $5200 \mathrm{~cm}$ long sedimentary core (COL17-3) retrieved from Colônia basin (2352' S, 4642'20” W, 900 m a.s.1.) in August 2017 using a built-in pushing corer with rotary tubing mounted on a $6 \mathrm{~T}$ 
Caterpillar drilling rig, and posteriorly sub-sampled every 3 $\mathrm{cm}$ for diatom analysis. The age model based on radiocarbon dates, OSL authigenic ${ }^{10} \mathrm{Be} /{ }^{9} \mathrm{Be}$ and paleomagnetism provided an age of 1.5 Ma at the base of the core (SimON et al. 2020). Samples corresponding to depth of 4376-77 cm and 4910-11 $\mathrm{cm}$ were selected for this study for including Planothidium material, which were respectively dated at 1.3 and $1.41 \mathrm{Ma}$, which matches with the Pleistocene period. See LEDRU et al. (2015) for detailed information on the Colônia basin geology and history.

A slice of sediment (about $0.5 \mathrm{~g}$ ) was oxidized for 2-6 $\mathrm{h}$ in hot $\mathrm{H}_{2} \mathrm{O}_{2}$ and $\mathrm{HCl}$ according to BatTaRbeE (1986). Afterwards, the cleaned material was repeatedly rinsed with distilled water to neutrality, and the oxidized material was mounted using Naphrax (R.I. = 1.74). Diatoms were examined under LM at $1000 \times$ magnification using a Zeiss Axio Imager A2 light microscope equipped with DIC and a digital camera model AxioCamMR5. Relative abundance was estimated by counting at least 400 valves in total at an efficiency count of at least 90\% (PAPPAS \& STOERMER 1996). For SEM, analysis were performed at the LIST, Luxembourg Institute of Science and Technology and at the Instituto de Química - USP, Universidade de São Paulo. For the first one, subsamples of the oxidized suspensions were filtered and rinsed with additional deionized water through a $3 \mu \mathrm{m}$ isopore polycarbonate membrane filter (Merck Millipore), subsequently attached to aluminum stubs and coated with platinum using a BAL-TEC MED 020 Modular High Vacuum Coating System for $30 \mathrm{~s}$ at $100 \mathrm{~mA}$. An ultra-high-resolution analytical field emission (FE) scanning electron microscope Hitachi SU-70 (Hitachi High-Technologies Corporation, Tokyo, Japan) operated at 5 $\mathrm{kV}$ and $10 \mathrm{~mm}$ distance was used for the analysis. SEM images were taken using the lower (SE-L) detector signal. Also, parts of the oxidized material were placed on aluminum stubs and coated with gold at $1 \mathrm{kV}$ for $5 \mathrm{~min}$ in a Balzers Sputtering/ SDC030 sputter coater at the Instituto de Botânica, and SEM observations were made with a Jeol - JSM 7401F (FEG) operated at $5 \mathrm{kV}$ at the Instituto de Química - USP. Photomicrographs were digitally edited and plates containing light and scanning electron microscopy images were created using CorelDraw X8.

We performed a non-metric multi-dimensional scaling (nMDS) ordination analysis based on Bray-Curtis dissimilarities to compare morphological differences between similar species. The total of 62 specimens were examined based in the new species type material $(\mathrm{n}=36)$ and literature information $(\mathrm{n}=$ 26). Basic morphometric values were taken into account: (i) valve width, (ii) length, (iii) number of striae in $10 \mu \mathrm{m}$, and (iv) valve width and length ratio. Permutational multivariate analysis of variance (PERMANOVA; 999 permutations) was used to examine the statistical significance of the differences. Data were analyzed using the 'vegan' package (OKSANEN et al. 2016) in R version 3.1.2 (R Development Core TeAm 2015). Holotype permanent slides and cleaned samples were deposited at the "Herbário Científico do Estado Maria Eneyda P. Kauffmann Fidalgo" (SP), São Paulo State Department of Infrastructure and Environment, Brazil. Isotype slides are deposited at the Botanic Garden Meise (BR), Belgium.

\section{ObSERVATIONS}

Planothidium scrobiculatum, Marquardt et C.E.Wetzel sp. nov. (Figs 1-36 LM; 37-48 SEM)

LM description: (RV: Figs 1-18; SV: Figs 1-36) - Valves lanceolate to elliptic-lanceolate with convex margins and cuneate apices, smaller valves sometimes with rounded apices (Fig. 34). Valve dimensions $(\mathrm{n}=36)$ : 9.2-28.2 $\mu \mathrm{m}$ length, $5.5-9 \mu \mathrm{m}$ width. (Figs 1-18) - Axial area linear to narrowly lanceolate. Central area with 1 unilateral large horseshoe-shaped hyaline area, with a relatively large cavum. Striae radiating throughout the entire valve, 10-13 in $10 \mu \mathrm{m}$. Areolae not discernible in LM. (Figs 19-36) - Axial area very narrow, linear, only slightly widening towards the central area. Central area is small, rounded, sometimes slightly asymmetric (Fig. 3) to almost absent in the smallest valves (Figs 17, 18), bordered on each side by usually two irregularly shortened radiate striae. Raphe branches are straight, with expanded, drop-like proximal raphe endings. Terminal raphe fissures are not discernible in LM. Striae radiate throughout the entire valve, never convergent near the apices, $12-13$ in 10 $\mu \mathrm{m}$. Areolae are not discernible in LM.

SEM observations: RV (Figs 37-40) - Externally, striae are broader than the virgae, composed of 3-5 (6 near apices) rows of small rounded areolae (Figs 37, 38). Proximal external raphe endings expanded, relatively close to each other (Figs 37, 38). Distal raphe fissures are bent to the same direction, continuing shortly onto the valve mantle (Figs 37, 38). Internally, central raphe endings deflected into opposite directions near the large, rounded central nodule (Figs 39, 40). Distal raphe ends terminate internally in small helictoglossae (Figs 39, 40). SV (Figs 41-48) - Externally striae composed of 2-4 rows of nearly rounded irregular sized areolae (usually 3 ), the middle row being slightly smaller than the parallel outer rows (Figs 41-45). Striae portion near the axial area often composed of 2 rows of areolae (Figs 41-45). Near the valve mantle, striae reach up to 4 areolae and are not interrupted near the valve mantle junction (Figs 41-45). Mantle areolae are grouped in 3 or 4 rows, each composed of 2 to 3 areolae (Figs 41-45).

Table 1. PERMANOVA test performed on morphological differences resulting groups in the nMDS using the Bray-Curtis distance measure.

\begin{tabular}{lllllll}
\hline & Df & SumsOfSqs & MeanSqs & F.Model & R2 & $\operatorname{Pr}(>$ F $)$ \\
\hline Species & 1 & 0.075 & 0.075 & 16.453 & 0.215 & 0.001 \\
Residuals & 60 & 0.275 & 0.005 & & 0.785 & \\
Total & 61 & 0.350 & & & 1 & \\
\hline
\end{tabular}


Numerous small superficial depressions present along the axial area, cavum and virgae (Figs 41-45). Sharp straight depression lines irregularly occurring on the axial area, but also transapically oriented on the virgae (Figs 41-43). Internally, a well-developed cavum is present with borders joined to the neighbour interstriae (Figs 46, 48). Striae internally sunken between raised virgae (Figs 46, 48).

Etymology: The specific epithet "scrobiculatum", Latin for 'pitted', refers to the rapheless valve pattern surface quite unusual in other Planothidium species.
Type locality: Brazil. São Paulo, Parelheiros District: Colônia basin (2352'S, 4642'20"W, 900 m a.s.1.), sediment core, present at the 4376-77 and 4910-11 cm depth, respectively dated at $\sim 1.3$ and 1.41 Ma., leg. M.-P. Ledru \& A.O. Sawakuchi, Aug. 2017.

Holotype: SP!, slide SP365549 (Herbário Científico do Estado "Maria Eneyda P. Kauffmann Fidalgo", São Paulo, from $4910-11 \mathrm{~cm}$ depth $(\sim 1.41 \mathrm{Ma})$ in the COL17-3 core, Brazil, here depicted in Figs 1-36). The holotype specimen is shown in Fig. 5 (RV) and Fig. 21 (SV).

Isotype: BR! slide BR 4595 (Meise Botanic Garden, Meise, Belgium).

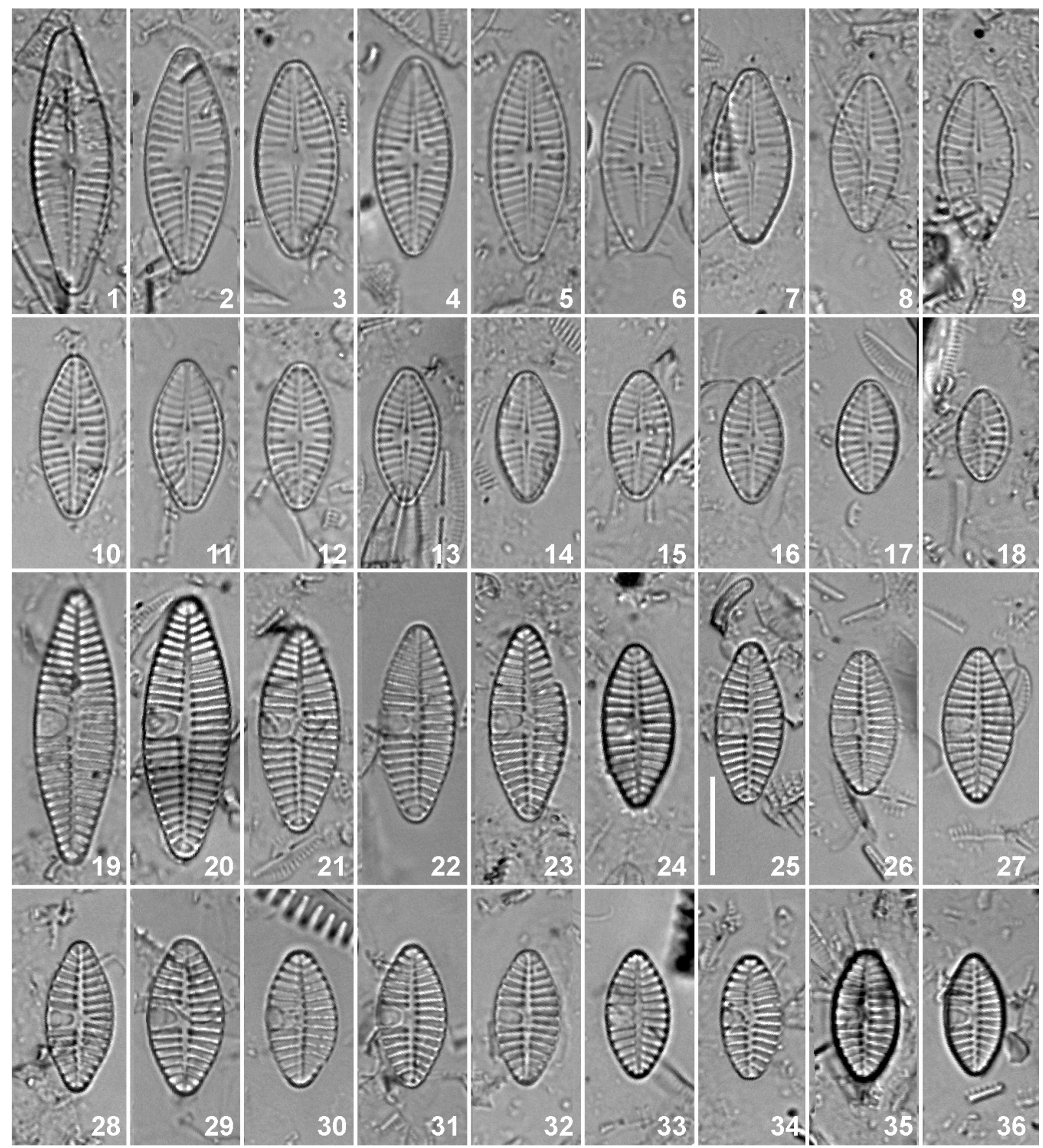

Figs 1-36. LM micrographs of Planothidium scrobiculatum Marquardt et C.E.Wetzel sp. nov. from holotype slide SP365549 sampled from Colônia basin, São Paulo, Brazil: (1-18) raphe valve view; (19-36) rapheless sternum valve view. Scale bar $10 \mu \mathrm{m}$. 
Associated diatom species: Populations of the new species are not very large and their maximum relative abundances in the selected slide is $7.9 \%$. Among the species found in the holotype slide, dominant taxa are Naviculadicta sp. (70.8\%), Pseudostaurosira sp. (3.7\%), and Staurosirella cf. crassa (4.2\%). The ongoing paleoenvironmental reconstruction along the retrieved core aims at elucidating the proper identity of observed taxa.

\section{Discussion}

An extensive literature search found a few Planothidium species with a morphology similar to P. scrobiculatum Marquardt et C.E.Wetzel sp. nov., but none of them shared the combination of features of the present new species.
Indeed, one diagnostic characteristic of the new species is the unusual, numerous small superficial depressions present externally on the SV, along the axial area, cavum and virgae, which was not previously described for any Planothidium species. In addition, based on LM and SEM morphology, P. scrobiculatum shows a particular combination of features that are sufficient to separate the new species from all others, such as: (1) lanceolate valvar outline with cuneate apices, (2) multiseriate striae composed of 2-4 rows of irregular sized areolae at the $\mathrm{SV}$, which are not interrupted at the valve mantle junction, and (3) areolae on the valve mantle are grouped in 3 or 4 rows, each composed of 2 to 3 areolae on SV. Nevertheless, a few species are worth of some consideration and a detailed comparison is discussed below.

Planothidium comperei C.E.Wetzel, N'Guessan
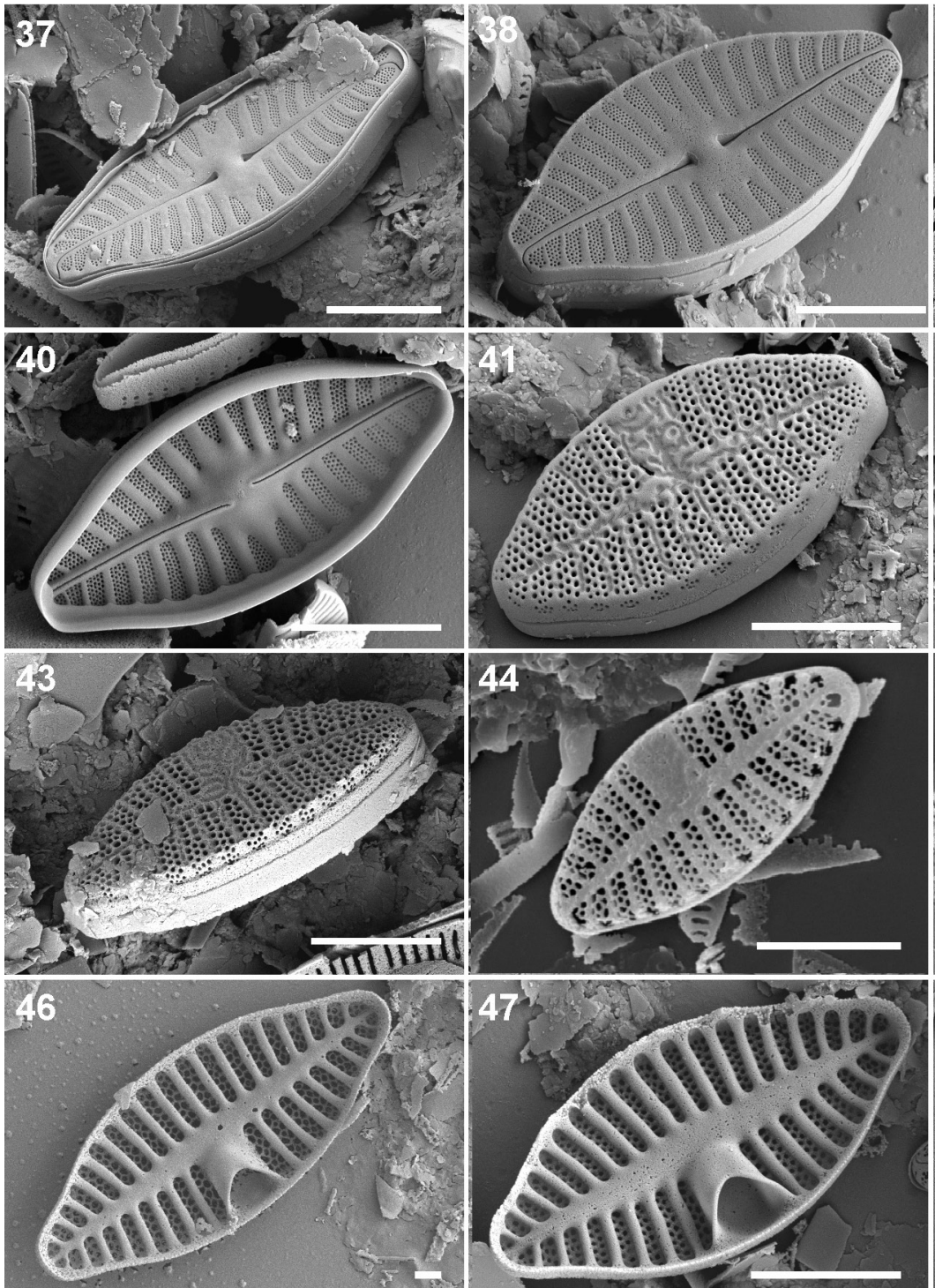
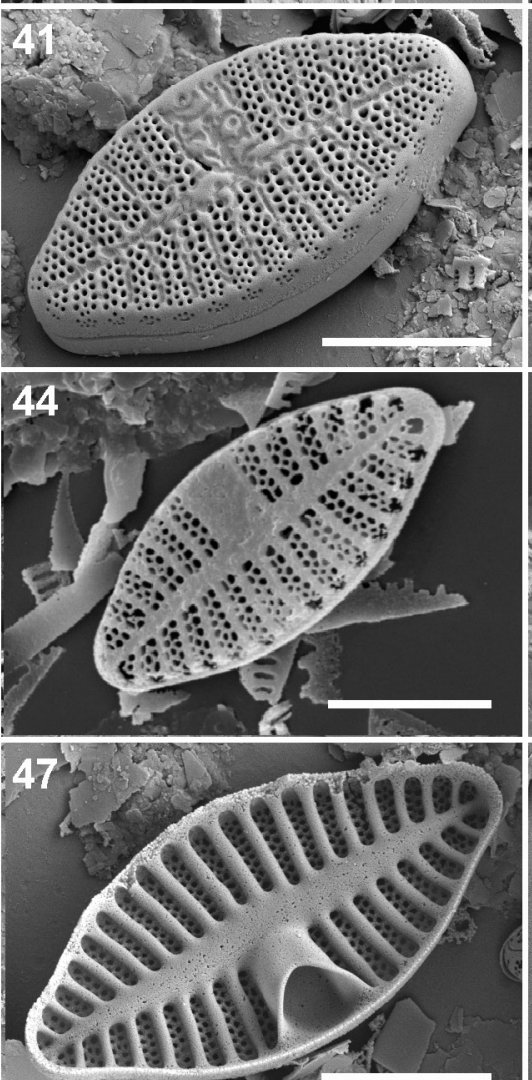
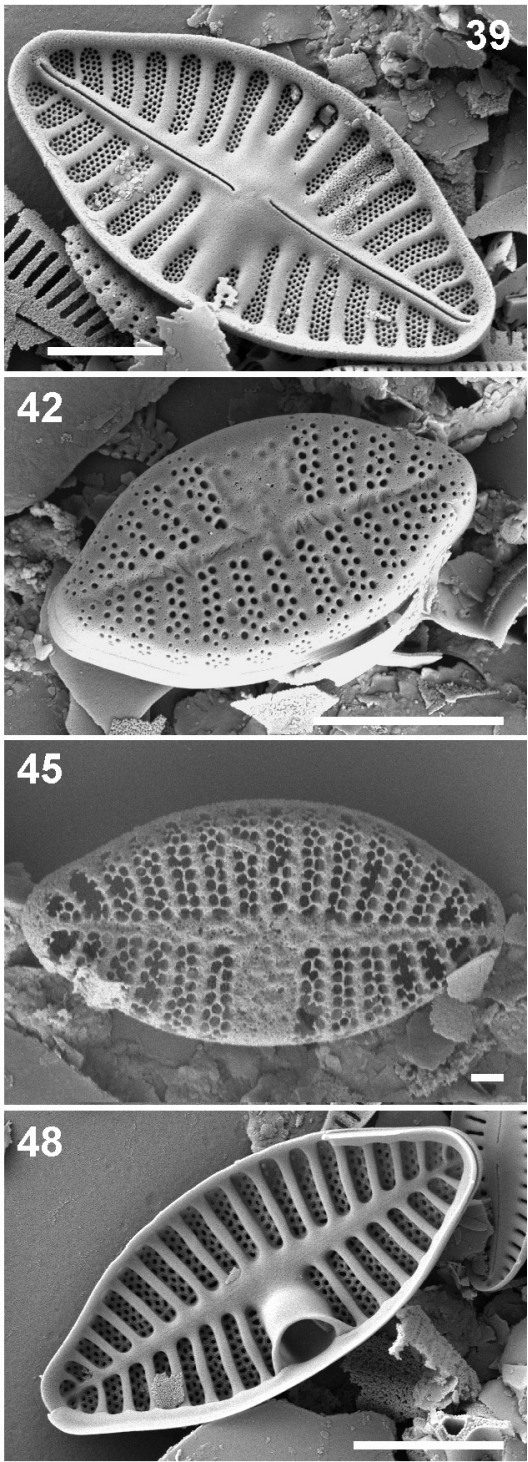

Figs 37-48. SEM micrographs of Planothidium scrobiculatum Marquardt et C.E.Wetzel sp. nov. from type material SP365549 (4910-11 cm depth; Figs 43-46) and material SP365548 (4376-77 cm depth; Figs 37-42, 47, 48) sampled from Colônia basin, São Paulo, Brazil: (37, 38) external raphe valve view; $(39,40)$ internal raphe valve view; $(41-43)$ external rapheless sternum valve view. Note the numerous small superficial depressions. $(41,43)$ note sharp straight depression lines irregularly occurring on the axial area and transapically oriented on the virgae; $(44,45)$ internal rapheless valve; detail of cavum aperture. Scale bars $5 \mu \mathrm{m}(37-44,47,48), 1 \mu \mathrm{m}(45,46)$. 
et Tison-Rosebery (N'GUESSAN et al. 2014), a tropical species from Ivory Coast, shares some similarity with $P$. scrobiculatum due to its lanceolate valve outline and the rounded central area. Moreover, $P$. comperei has rostrate apiculate apices, elongated when compared to the cuneate apices of the new species. The nMDS ordination space (Fig. 49) revealed significant differences between them (PERMANOVA, $\mathrm{F}=16.453, \mathrm{p}<0.001$; Table 1) providing a sufficient basis for distinguishing them as separate species. Regarding the SV, SEM observation reveals differences in terms of surface roughness between both species. Whereas $P$. comperei valve surface has round, shallow irregular depressions along the apical axis, $P$. scrobiculatum not only shows the typical numerous small superficial depressions along the axial area, cavum and virgae, but also with sharp straight depression lines irregularly occurring on the axial area and transapically oriented on the virgae (Figs 41-43). Finally, one row of irregular sized areolae (2-4) is present on the valve mantle of $P$. comperei. However, in the present new species mantle areolae are grouped in 3 or 4 rows, each composed of 2 to 3 areolae (Figs 42-43) with a less evident interruption in the valve mantle junction (Figs 41-45) when compared to the clearly interrupted striae in $P$. comperei.

Planothidium hinzianum C.E.Wetzel, Van de Vijver et Ector (WeTzEL et al. 2019) described from northern Germany shows some characteristics similar to those of $P$. scrobiculatum, such as the abruptly interrupted striae on the valve mantle junction, as well as the mantle areolae grouped in small groups of up to 9 (WETZEL et al. 2019). However, P. hinzianum has round, acutely apices opposite to the cuneate ones of P. scrobiculatum. Planothidium hinzianum has also a relatively broad asymmetrical axial area in the SV, and an asymmetrical

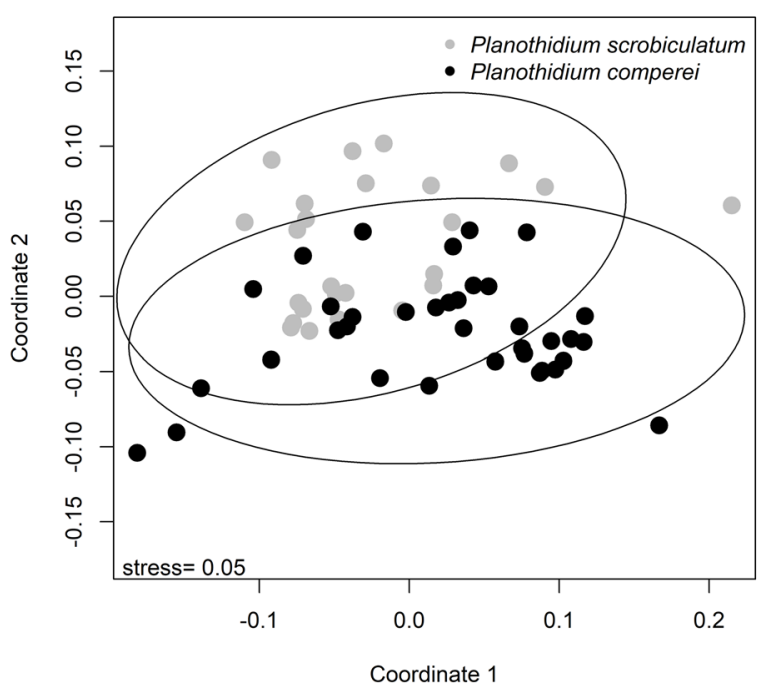

Fig. 49. Non-metric multi-dimensional scaling (nMDS) ordination of $P$. scrobiculatum from type material SP365549 (4910-11 cm depth; black circle) and $P$. comperei from N'GuESSAN et al. (2014; grey circle) based on four morphological characters and distinguished by cluster analysis (symbols). wedge-shaped central area in the RV, bordered on each side by $1-2$ shortened striae and lacking striae on the other side. In contrast, P. scrobiculatum presents from linear to narrowly lanceolate axial area (SV) and a small and rounded central area (RV) (Figs 1-36).

From the Andean mountains of South America, a similar cavum-bearing taxon worth comparison is Planothidium infrequens Lange-Bertalot et Rumrich (RUMrich et al. 2000: 212, pl. 27, figs 3-9), which share similarities regarding SV that show the same areolae structures and numbers. Planothidium infrequens, however, has distinct rostrate apices. In contrast, Planothidium rhombicuneatum Lange-Bertalot et Rumrich (RUMRICH et al. 2000: 214, pl. 29, figs 1-12) presents the same valve outline as $P$. scrobiculatum, but does not possess a cavum. Instead, it shows a wide unilateral sinus on the SV. Differences between $P$. infrequens and P. comperei are discussed in N'GuESSAN et al. (2014). Based on this study, P. scrobiculatum presents larger valve dimensions when compared to $P$. infrequens.

From the Holarctic region, specifically at the Lake Baikal a place known for its high endemism rates, three interesting Planothidium that share similar valve outlines with $P$. scrobiculatum, but have distinct ultrastructural elements, such as striae patterns, valve surface, and lack of cavum: Planothidium baicalorhombicum Kulikovskiy et Lange-Bertalot (KuLIKovSKIY et al. 2015: 59, pl. 68, figs 1-18), Planothidium rugosum Kulikovskiy et Lange-Bertalot (KuLIKovsKiY et al. 2015: 286, pl. 68, figs 19-23), and Planothidium baicalacutum Kulikovskiy et Lange-Bertalot (KuLIKovsKIY et al. 2015: 57, pl. 66, figs 1-10). A fourth taxon, Planothidium makarevichae Kulikovskiy et Lange-Bertalot (KULIKOvSKIY et al. 2015: 286, pl. 72, figs 1-14) has the same valve outline and a cavum, but with much shorter striae on the SV valve and a distinct (oval) central area on the SV.

WETZEL et al. (2019) has discussed the importance of characteristic features mainly present on the SV during Planothidium identification. Among these features, the authors highlighted the pattern of valve surface smoothness (with irregular lines on the axial area and virgae or showing 'round' depressions instead), the number of areolae per stria, the striae interrupted or not towards valve mantle, and consequently the number of areolae on the mantle. Therefore, P. scrobiculatum is different from all other similar species under LM and SEM by recognizable characters or character combination. In this study, the SV surface roughness showed small differences among some individuals currently analyzed, sometimes less pronounced (Fig. 41) compared with other specimens (Figs 42, 43). Probably, factors such as valve reduced size, as well as the state of deterioration should be considered.

Finally, the Colônia basin Pleistocene diatom flora showed to be quite diverse, and new species are being described. Distribution of $P$. scrobiculatum in Brazil is yet to be known and, so far, the taxa described in this paper has been observed only as fossil from the 
Pleistocene. This study contributes to the knowledge of the hitherto understudied microorganism biodiversity of tropical regions. In addition, such patterns of diversity and the wealth of new diatom taxa in and around Colônia basin (many yet to be fully described) suggest that further samplings from other fossil localities may provide insight into its habitat preferences and range. In addition, this is an area of unique biological entity, therefore, requires further studies.

\section{ACKNOWLEDGEMENTS}

This research is part of the projects "Dimensions of biodiversity" FAPESP (BIOTA 2013/50297-0), NSF (DEB 1343578) and NASA, the International Continental Deep Drilling Program (ICDP), "UVTrop" INSU LEFE, the Labex-CEBA, "TROPICOL" Foundation BNP Paribas "Climate Initiative" (2017-2020) and "Challenges for biodiversity conservation" (FAPESP 2017/50341-0). GCM thanks FAPESP (Fundação de Amparo à Pesquisa do Estado de São Paulo) for the Post Doctoral fellowship (2018/103142) developed at the Instituto de Botânica, Ecology Department. DCB and CEMB thank CNPq (Conselho Nacional de Desenvolvimento Científico e Tecnológico, for Research Fellowships (310176/2019-0 and 305031/2016-3). We gratefully acknowledge Dr. A.O. Sawakuchi as well all the technicians and researchers involved in the sampling and preparation of the material currently analyzed.

\section{REFERENCES}

Álvarez-Blanco, I. \& Blanco, S. (2013): Planothidium galaicum sp. nov. (Bacillariophyta, Achnanthidiaceae), a new diatom species from Galician coast, Spain. - Phytotaxa 151: 44-52. https://doi.org/10.11646/phytotaxa.151.1.4

AuER, V. (1959): The Pleistocene of Fuego-Patagonia, 3: shorelines displacements. - Annales Academiæ Scientiarum Fennicæ, Series A, III. Geologica-Geographica 60: 1-247.

BąK, M. \& LANGE-Bertalot, H. (2014): Four small-celled Planothidium species from Central Europe proposed as new to science. - Oceanological and Hydrobiological Studies 43: 346-359. https://doi.org/10.2478/ s13545-014-0152-9

BartozeK, E.C.R.; Zorzal-Almeida, S. \& Bicudo, D.C. (2018): Surface sediment and phytoplankton diatoms across a trophic gradient in tropical reservoirs: new records for Brazil and São Paulo State. - Hoehnea 45: 69-92. https://doi.org/10.1590/2236-8906-51/2017

Battarbee, R.W. (1986): Diatom analysis. - In: BerGLund, B.E. (ed.): Handbook of Holocene Palaeoecology and Palaeohydrology. - pp. 527-570, Wiley, Chichester.

Blanco, S.; Álvarez-Blanco, I.; Cejudo-Figueiras, C.; Recio EsPejo, J.M.; BorJa Barrera, C.; BéCARes, E.; Díaz del Olmo, F. \& CÁmara Artigas, R. (2013): The diatom flora in temporary ponds of Doñana National Park (southwest Spain): five new taxa. Nordic Journal of Botany 31: 489-499. https://doi. org/10.1111/j.1756-1051.2013.01691.x

Brindle, M.; Mohan, J.; Beck, C. \& Stone, J.R. (2018): Three novel species of Bacillariophyta (diatoms) in the genera Surirella and Thalassiosira from Pleistocene Paleolake Lorenyang ( 2-1.6 Ma), Turkana Basin, Kenya. Phytotaxa 371: 230-240. https://doi.org/10.11646/ phytotaxa.371.3.6

BukhtiYArova, L.M. \& Lyakh, A.M. (2014): Functional morphology of the horseshoe spot in the frustule of
Planothidium species (Bacillariophyta). - Ukrainian Botanical Journal 71: 223-227. https://doi.org/10.15407/ ukrbotj71.02.223

Cleve, P.T. \& Grunow, A. (1880): Beiträge zur Kenntniss der arctischen Diatomeen. - Kongliga Svenska VetenskapsAkademiens Handlingar 17: 1-121.

COMPÈRE, P. \& RiauX-Gobin, C. (2009): Diatomées de quelques biotopes marins, saumâtres et dulçaquicoles de Guinée (Afrique occidentale) [Diatoms from some marine, brackish and freshwater biotopes of Guinea (West Africa)]. - Systematics and Geography of Plants 79: 33-66.

COMPÈre, P. \& VAN DE VIJVER, B. (2009): Planothidium engelbrechtii (Cholnoky) Round \& Bukhtiyarova: identity and lectotypification (Bacillariophyta). - Fottea 9: 187-192. https://doi.org/10.5507/fot.2009.019

Cocquyt, C. (1998): Diatoms from the Northern Basin of Lake Tanganyika. - Bibliotheca Diatomologica 39: 1-276.

Cocquyt, C.; Vyvennan, W. \& Compère, P. (1993): A checklist of the algal flora of the East African Great Lakes (Malawi, Tanganyika and Victoria). - Scripta Botanica Belgica 8: 1-56.

Faria, D.M.; TREMARIN, P.I. \& LudWIG, T.A.V. (2010): Diatomáceas perifíticas da represa Itaqui, São José dos Pinhais, Paraná: Fragilariales, Eunotiales, Achnanthales e Gomphonema Ehrenberg [Periphytic diatoms from Itaqui reservoir, São José dos Pinhais, Paraná: Fragilariales, Eunotiales, Achnanthales and Gomphonema Ehrenberg]. - Biota Neotropica 10: 415-427. https://doi.org/10.1590/ s1676-06032010000300035

FERRARI, F. \& Ludwig, T.A.V. (2007): Coscinodiscophyceae, Fragilariophyceae e Bacillariophyceae (Achnanthales) dos rios Ivaí, São João e dos Patos, bacia hidrográfica do rio Ivaí, município de Prudentópolis, PR, Brasil [Coscinodiscophyceae, Fragilariophyceae and Bacillariophyceae (Achnanthales) of the Ivaí, São João and Patos rivers in the Ivaí basin, Prudentópolis, Paraná State, Brazil]. - Acta Botanica Brasilica 21: 421-441. https://doi.org/10.1590/s0102-33062007000200016

GASSE, F. (1980): Les diatomées lacustres Plio-Pléistocènes du Gadeb (Éthiopie): systématique, paléoécologie, biostratigraphie. - Revue Algologique: Mémoire Hors-Série 3: 1-249.

Gasse, F. (1986): East African diatoms: taxonomy, ecological distribution. - Bibliotheca Diatomologica 11: 1-201.

Gong, Z.; Li, Y.; Metzeltin, D. \& Lange-Bertalot, H. (2013): New species of Cymbella and Placoneis (Bacillariophyta) from late Pleistocene fossil, China. - Phytotaxa 150: 29-40. https://dx.doi.org/10.11646/phytotaxa.150.1.2

Hayashi, T. \& Tanimura, Y. (2015): Two new Cyclostephanos species, C. nepalensis and C. pseudonepalensis (Bacillariophyta), from middle Pleistocene sediments of the Paleo-Kathmandu Lake, Nepal. - Nova Hedwigia 101: 191-204. https://dx.doi.org/10.1127/ nova_hedwigia/2015/0264

Jahn, R.; AbARCA, N.; Gemeinholzer, B.; Mora, D.; SKibBE, O.; Kulikovskiy, M.; Gusev, E.; Kusber, W-H. \& ZimmermanN, J. (2017): Planothidium lanceolatum and Planothidium frequentissimum reinvestigated with molecular methods and morphology: four new species and the taxonomic importance of the sinus and cavum. - Diatom Research 32: 75-107. https://doi.org/10.108 0/0269249X.2017.1312548

Julius, M.L.; Curtin, M. \& TANAKa, H. (2006): Stephanodiscus kusuensis, sp. nov. a new Pleistocene diatom from Southern Japan. - Phycological Research 54: 294-301. 
https://doi.org/10.1111/j.1440-1835.2006.00436.x

KaczmarsKa, I. (1981): On Pleistocene Amphora thumensis (Mayer) Krieger (Bacillariophyceae). - Acta Palaeontologica Polonica 26: 364-369.

Khursevich, G.K.; Fedenya, S.A.; KuZmin, M.I.; Karabanov, E.B.; Williams, D.F. \& Prokopenko, A.A. (2003): Morphology of new taxa of Bacillariophyta from the Pliocene and Pleistocene deposits of Lake Baikal. International Journal on Algae 5: 85-102. https://doi. org/10.1615/InterJAlgae.v5.i3.70

Kociolek, J.P.; Blanco, S.; Coste, M.; Ector, L.; Liu, Y.; Karthrick, B.; KulikovskiY, M.; LundHOLM, N.; Ludwig, T.; Potapova, M.; Rimet, F.; Sabbe, K.; Sala, S.; Sar, E.; TAYlor, J.; VAn de VijVer, B.; Wetzel, C.E.; WiLliams, D.M.; Witkowski, A. \& WitKowski, J. (2020): DiatomBase. - http://www.diatombase.org. Accessed 27 August 2020

Korsakova, O.; Kolka, V. \& Semenova, L. (2016): Late Pleistocene stratigraphy according to the sediment sequence from eastern Kola Peninsula, Ponoi River Valley (North-Western Russia). - Quaternary International 420: 280-293. https://doi.org/10.1016/j.quaint.2015.11.101

Kulikovskiy, M.S.; Lange-Bertalot, H. \& Kuznetsova, I.V. (2015): Lake Baikal: hotspot of endemic diatoms, 2.Iconographia Diatomologica 26: 1-656.

Lange-Bertalot, H. (1999): Neue Kombinationen von Taxa aus Achnanthes Bory (sensu lato). - Iconographia Diatomologica 6: 276-289.

Ledru, M-P.; Reimold, W.U.; Ariztegui, D.; BARD, E.; Crósta, A.P.; Riccomini, C.; SawakUChi, A.O. \& workshop participants. (2015): Why deep drilling in the Colônia Basin (Brazil)? - Scientific Drilling 20: 33-39. https:// doi.org/10.5194/sd-20-33-2015

McLaughlin, R.B. \& Stone, J.L. (1986): Some Late Pleistocene diatoms of the Kenai Peninsula, Alaska. - Nova Hedwigia Beiheft 82: 5-118.

Metzeltin, D. \& Lange-Bertalot, H. (1998): Tropische Diatomeen in Südamerika, 1: 700 überwiegend wenig bekannte oder neue Taxa repräsentativ als Elemente der neotropischen Flora. - Iconographia Diatomologica 5: $1-695$.

Metzeltin, D. \& Lange-Bertalot, H. (2007): Tropical diatoms of South America, 2: special remarks on biogeographic disjunction. - Iconographia Diatomologica 18: 1-877.

Metzeltin, D., Lange-Bertalot, H. \& García-RodrígueZ, F. (2005): Diatoms of Uruguay compared with other taxa from South America and elsewhere. - Iconographia Diatomologica 15: 1-736.

NAYA, T. (2012): Marine Thalassiosira species from coastal Pleistocene sediments in central Kanto Plain, Japan. Diatom Research 27: 141-163. https://doi.org/10.108 0/0269249X.2012.704883

N'Guessan, K.R.; Wetzel, C.E.; Ector, L.; Coste, M.; Cocquyt, C.; Van de ViJver, B.; Yao, S.S.; Ouattara, A.; Kouamelan, E.P. \& Tison-Rosebery, J. (2014): Planothidium comperei sp. nov. (Bacillariophyta), a new diatom species from Ivory Coast. - Plant Ecology and Evolution 147: 455-462. https://doi.org/10.5091/ plecevo.2014.981

Novis, P.M.; Braidwood, J. \& Kilroy, C. (2012): Small diatoms (Bacillariophyta) in cultures from the Styx River, New Zealand, including descriptions of three new species. - Phytotaxa 64: 11-45. https://doi.org/10.11646/ phytotaxa.64.1.3

O'BRIEN, N.R. (1968): Electron microscope study of Pleistocene diatoms. - Maritime Sediments 4: 7-10.

OKsanen, J.F.; BLANChet, G.; KIndt, R.; LegendRe, P.; Minchin, P.R.; O'Hara, R.B.; Simpson, G.L.; Solymos, P.; HenrY, M.H. \& Stevens, W.H. (2016): Vegan: Community Ecology Package. R package version 2.3-5. - Available online at https://CRAN.R-project.org/package=vegan

Olshtynska, A. \& Tymchenko, Y. (2018): A new species of Cymatopleura W. Smith (Bacillariophyta) from the Upper Pleistocene sediments of the Black Sea. - Nova Hedwigia Beiheft 147: 151-160. https://doi.org/10.1127/ nova-suppl/2018/014

Panagiotopoulos, K.; Holtvoeth, J.; Kouli, K.; Marinova, E.; Francke, A.; CvetKoska, A.; Jovanovska, E.; Lacey, J.H.; Lyons, E.T.; Buckel, C.; Bertini, A.; Donders, T.; Just, J.; LeICHER, N.; LenG, M.J.; Melles, M.; Pancost, R.D.; SAdori, L.; TAuber, P.; Vogel, H.; Wagner, B. \& WiLKe, T. (2020): Insights into the evolution of the young Lake Ohrid ecosystem and vegetation succession from a southern European refugium during the Early Pleistocene. - Quaternary Science Reviews 227: 106044. https://doi.org/10.1016/j. quascirev.2019.106044

Pappas, J.L. \& Stoermer, E.F. (1996): Quantitative method for determining a representative algal sample count. - Journal of Phycology 32: 693-696. https://doi. org/10.1111/j.0022-3646.1996.00693.x

Potapova, M.G. (2012): New species and combinations in monoraphid diatoms (family Achnanthidiaceae) from North America. - Diatom Research 27: 29-42. https:// doi.org/10.1080/0269249X.2011.644636

R Development Core Team (2015): R: a language and environment for statistical computing. R Foundation for Statistical Computing, Vienna, Austria. - Available online at http://www.R-project.org/.

RiauX-Gobin, C.; Compère, P.; Al-Handal, A.Y. \& Straub, F. (2012): SEM survey of some small-sized Planothidium (Bacillariophyta) from coral sands off Mascarenes (Western Indian Ocean). - Nova Hedwigia Beiheft 141: 295-314.

RiauX-Gobin, C.; Witkowski, A.; Igersheim, A.; Lobban, C.S.; Al-Handal, A.Y. \& CoMpère, P. (2018): Planothidium juandenovense sp. nov. (Bacillariophyta) from Juan de Nova (Scattered Islands, Mozambique Channel) and other tropical environments: a new addition to the Planothidium delicatulum complex. - Fottea 18: 106-119. https://doi.org/10.5507/fot.2017.019

Round, F.E. \& BukhtiYARova, L. (1996): Four new genera based on Achnanthes (Achnanthidium) together with a re-definition of Achnanthidium. - Diatom Research 11: 345-361. https://doi.org/10.1080/0269249X.1996.9705389

Rovira, L.; Witkowski, A.; Trobajo, R.; Ruppel, M. \& IBÁÑEZ, C. (2011): Planothidium iberense sp. nov., a new brackish diatom of the Ebro Estuary, northeast Spain. - Diatom Research 26: 99-107. https://doi.org /10.1080/0269249X.2011.587645

Rumrich, U.; Lange-Bertalot, H. \& Rumrich, M. (2000): Diatomeen der Anden: von Venezuela bis Patagonien/ Feuerland [Diatoms of the Andes: from Venezuela to Patagonia/Tierra del Fuego]. - Iconographia Diatomologica 9: 1-649.

RuwER, D.T. \& RoDrigues, L. (2018): Subfossil and periphytic diatoms from the upper Paraná River, Brazil: last $\sim 1000$ years of a transition period. - Hoehnea 45: 431-449. https://doi.org/10.1590/2236-8906-89/2017

Simon, Q.; Ledru, M.-P.; SAWAKUChI, A.O.; FaVIER, C.; Minelli, 
T.D.; Grohman, C.H.; Guedes, M.; Bard, E.; ThouvenY, N.; Garcia, M.; Tachikawa, K.; RodríGuez-Zorro, P.A. \& ASTER TEAm (2020): Chronostratigraphy of a 1.5 \pm 0.1 Ma composite sedimentary record from Colônia basin (SE Brazil): Bayesian modeling based on paleomagnetic, authigenic ${ }^{10} \mathrm{Be} /{ }^{9} \mathrm{Be}$, radiocarbon and luminescence dating. - Quaternary Geochronology 58: 101081. https://doi.org/10.1016/j.quageo.2020.101081

Spaulding, S.; Edlund, M. \& Metzeltin, D. (2008): Planothidium. - In: Diatoms of North America. https://diatoms.org/ genera/planothidium. Accessed 08 June 2020.

Spaulding, S.A.; Stone, J.R.; Norton, S.A.; Nurse, A. \& SAROS, J.E. (2020): Paleoenvironmental context for the Late Pleistocene appearance of Didymosphenia in a North American alpine lake. - Aquatic Sciences 82: 10. https://doi.org/10.1007/s00027-019-0681-9

Stancheva, R. (2019): Planothidium sheathii, a new monoraphid diatom species from rivers in California, USA. Phytotaxa 393: 131-140. https://doi.org/10.11646/ phytotaxa.393.2.4

TANaka, H. \& Kobayasi, H. (1996): The fine structure of Cyclotella rhomboideo-elliptica Skuja, from a Middle Pleistocene Deposit, Gunma Prefecture, Central Japan. - Diatom 12: 35-41. https://doi.org/10.11464/diatom1985.12.0_35

TANaka, H. \& Nagumo, T. (2000): Cyclostephanos numataensis sp. nov., a new Pleistocene diatom from Central Japan. - Diatom 16: 19-25. https://doi.org/10.11464/ diatom1985.16.0_19

VAN De ViJVer, B. \& BosaK, S. (2019): Planothidium kaetherobertianum, a new marine diatom (Bacillariophyta) species from the Adriatic Sea. - Phytotaxa 425: 105-112. https://doi.org/10.11646/phytotaxa.425.2.5

VAN DE ViJVER, B.; WetZeL, C.E. \& ECTOR, L. (2018): Analysis of the type material of Planothidium delicatulum (Bacillariophyta) with the description of two new Planothidium species from the sub-Antarctic Region. Fottea 18: 200-211. https://doi.org/10.5507/fot.2018.006

Van de Vijver, B.; Wetzel, C.; Kopalová, K.; Zidarova, R. \& ECTOR, L. (2013): Analysis of the type material of Achnanthidium lanceolatum Brébisson ex Kützing
(Bacillariophyta) with the description of two new Planothidium species from the Antarctic Region. Fottea 13: 105-117. https://doi.org/10.5507/fot.2013.010 VANLANDINGHAM, S.L. (1990): Observations on the biostratigraphy of Pliocene and Pleistocene diatomites from the Terrebonne district, Deschutes County, Oregon. - Micropaleontology 36: 182-196. https:// doi.org/10.2307/1485503

Wetzel, C.E. \& Ector, L. (2014a): Taxonomy, distribution and autecology of Planothidium bagualensis sp. nov. (Bacillariophyta) a common monoraphid species from southern Brazilian rivers. - Phytotaxa 156: 201-210. https://doi.org/10.11646/phytotaxa.156.4.2

Wetzel, C.E. \& ECTOR, L. (2014b): Planothidium lagerheimii comb. nov. (Bacillariophyta, Achnanthales) a forgotten diatom from South America. - Phytotaxa 188: 261-267. https://doi.org/10.11646/phytotaxa.188.5.3

Wetzel, C.E.; Van de Vijver, B.; Blanco, S. \& Ector, L. (2019): On some common and new cavum-bearing Planothidium (Bacillariophyta) species from freshwater. - Fottea 19: 50-89. https://doi.org/10.5507/fot.2018.016

Wetzel, C.E.; Van de Vijver, B.; Hoffmann, L. \& Ector, L. (2013): Planothidium incuriatum sp. nov., a widely distributed diatom species (Bacillariophyta) and type analysis of Planothidium biporomum. - Phytotaxa 138: 43-57. https://doi.org/10.11646/phytotaxa.138.1.6

WorNARDT, W.W. (1964): Pleistocene diatoms from Mono and Panamint Lake Basins California. - Occasional papers of the California Academy of Sciences 46: 1-27.

Yasui, S. \& Kobayashi, I. (2001): Pleistocene-Holocene diatom floras of the Shiotsugata Lagoon in the Echigo Plain, central Japan. - Science Reports of Niigata University, Ser. E (Geology) 16: 47-81.

(C) Czech Phycological Society (2021)

Received July 6, 2020

Accepted November 4, 2020 